Article

\title{
Eruption of Mount lle Lewotolok on November 29, 2020: A historical volcanic and tectonic seismicity assessment
}

\section{Andri Wibowo ${ }^{1, *}$}

Abstract. An eruption of volcano is related to the past volcanic and tectonic seismicity. Recently, on November 29, 2020, a 1423 m Mount lle Lewotolok in Lembata Island has erupted. In here, this paper aimed to assess the volcanic and tectonic seismicity as determinant factor and precursor of recent Mt lle Lewotolok eruption. The assessment shows that Mt Ile Lewotolok volcanic activities were characterized by both tectonic and deep volcanic seismicity. Since 2010, mean tectonic quake magnitudes of $\mathrm{M} 4.133$ (95\% $\mathrm{Cl}: \mathrm{M} 3.205-5.062$ ) have occurred at mean depth of $13.500 \mathrm{~km}(95 \% \mathrm{Cl}: 8.201-18.799 \mathrm{~km})$ within a distance of 3-4 km from the summit. Tectonic quake has occurred frequently in southwest of lle Lewotolok and this has contributed to the past eruptions in 2012 and 2017. Recent eruption has been influenced by deep volcanic seismicity rather than local tectonic. Based on November 2020 record, mean of deep volcanic seismicity frequency was 2.190 events/day $(95 \% \mathrm{Cl}: 1.136$ 3.243 events/day $\mathrm{km}$ ) that has outnumbered $\left(\mathrm{t}_{\text {test }}=2.665, \mathrm{P}=0.013\right.$ ) the events of local tectonic quakes (mean 0.621 events/day; $95 \% \mathrm{Cl}: 0.142$ 1.099 events/day). Prior to the eruption there was significant increase of deep volcanic seismicity $(P=0.023)$ while local tectonic quake was not showing an increasing trend $(P=0.764)$. This result confirms that the deep volcanic seismicity frequency is a precursor that may trigger the eruption and deep volcanic seismicity data can be used as indicator of volcanic activities.
Keywords: deep, eruption, precursor, seismicity, tectonic, volcano

\section{Introduction}

Volcanic eruption is a complex nature and geological conditions related to seismicity factors including volcanic and tectonic. Volcanic seismicity depends on the depth includes shallow and deep seismicity that occur at depth of $60 \mathrm{~km}$ beneath the volcano. While tectonic seismicity occurs around the volcano. Studying the presence of volcanic and tectonic seismicity around the active volcano is important since volcano eruption was theoritized triggered by seismicity. As a result, research on the interaction between volcanisms and tectonics has received many attentions in recent years. Several mountain eruptions were observed after seismic activities. In 1707, eruption at Mount Fuji, occurred after an earthquake of M 8.2 and after a M 7.7 earthquake in 1990, Mt. Pinatubo has erupted in 1991 (Hill et al. 2002). 
Ile Lewotolok (1423 m above sea level) is one of active volcano located in semiarid ecosystem of Lembata island in south east of Indonesia archipelago. This volcanic mountain has extensive history of eruption. A record on this volcanic activity was dated back to $17^{\text {th }}$ century. In 1660 , an eruption was observed in the central crater. Another eruption was recorded in 1819 and repeated again on October 6, 1849. First record on the impacts of this volcano eruption was on October 5 and 6, 1852. In this time, a solfatara complex has been reported on the eastern slope. Eruption was repeated again on 1864 ad 1889 with an eruption column has been observed. In 1920, another eruption has happened with eruption column.

An increase in volcanic activity has been observed from January 6 to February 3 and June 1939 and repeated again on December 15, 1951. Increasing seismic activity with tremors has been observed on January 2, 2012. Mount (Mt) lle Lewotolok has an increase in volcanic activity in the form of significant seismicity since October 7, 2017. Local tectonic earthquakes, deep volcanic and shallow volcanic have been recorded since mid-September 2017. Recently, on November 29, 2020, Mt lle Lewotolok has erupted again at $0845 \mathrm{~h}$. Considering this situation, this paper aimed to assess the volcanic and tectonic seismicity as determinant factors of recent Mt lle Lewotolok eruption.

\section{Materials and Methods}

The aerial visualization of Mt lle Lewotolok (Figure 1) was obtained based on Sentinel 2 L2A and Landsat $8 \mathrm{OLI}$ imageries. The satellite image then adjusted to natural color band combination to retrieve the eruption column. The volcanic and tectonic seismicity data were obtained from archive and latest records. Seismic monitoring activity to obtain the data was using Kinemetric seismic recorder with a seismometer sensor installed in the field. The recorded seismic data included deep volcanic, local tectonic and eruption quakes.
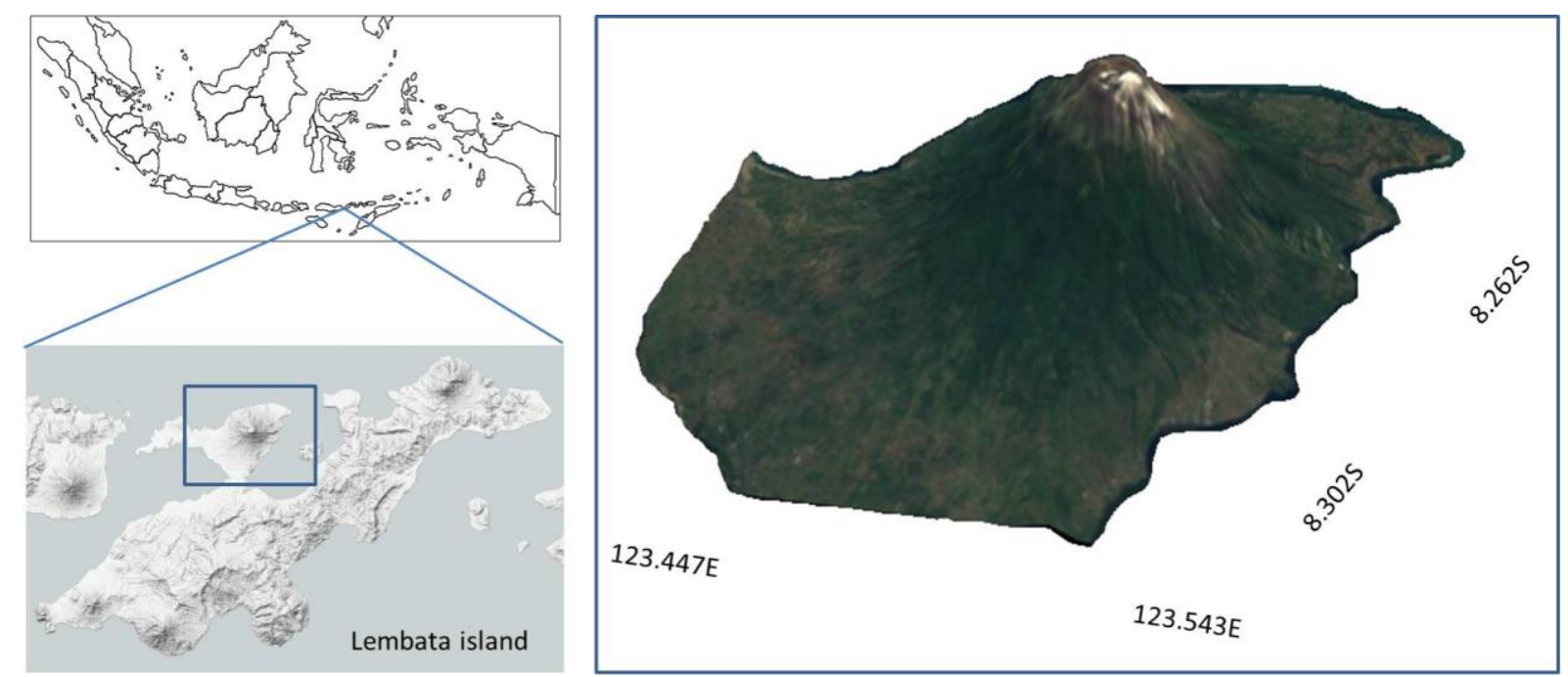

Figure 1. Location of volcanic Mt Ile Lewotolok in Lembata island 


\section{Results and Discussion}

The eruption column resulted from Mt lle Lewotolok eruption on Sunday, November 29, 2020, at $0845 \mathrm{~h}$ was observed to be $4000 \mathrm{~m}$ above the peak (5423 $\mathrm{m}$ above sea level). The eruption column was observed to be gray with thick intensity towards the east and west. Seismograph recorded this eruption has a maximum amplitude of $35 \mathrm{~mm}$ with 600 second duration. From above, the column has an increase in size (Figure 2). At the initial of eruption, the longest column diameter was $14 \mathrm{~km}$. The columns then increased in diameter almost 3 folds and elongated to south east directions of the island (Figure 2).
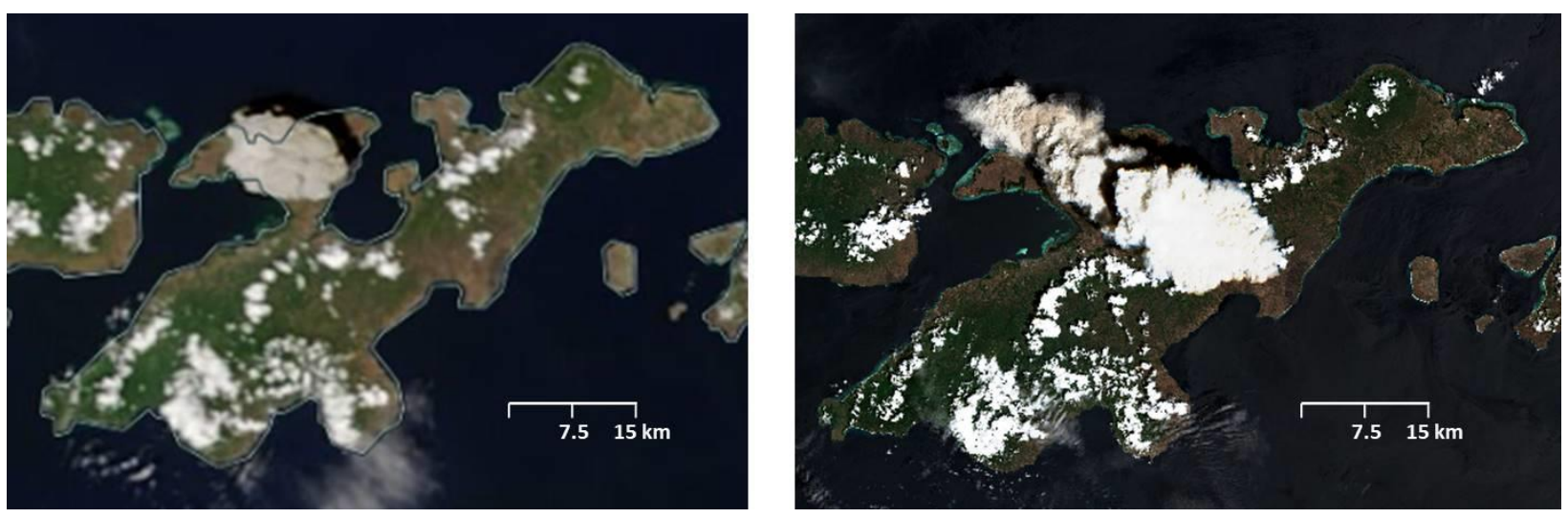

Figure 2. Eruption columns of Mt lle Lewotolok observed by Sentinel 2 L2A

The eruption of lle Lewotolok was characterized by several pre deep volcanic and local tectonic quakes. Figure 3 presents the frequency of pre deep volcanic and local tectonic quakes recorded 1 month before the eruption. The recording period was from November 1, 2020 to November 29, 2020 when eruption happened. It is apparent that there is a significant increase of deep volcanic quake events prior to the eruptions. Local tectonic quakes were also increasing whereas the frequency was declining prior to the eruption. The frequencies of deep volcanic quakes have outnumbered the local tectonic quakes. Eruption quakes were never occurred within the recording period whereas it has the highest values observed on the eruption day. Deep volcanic quake frequencies were observed having negative correlation with local tectonic quakes. An increase in deep volcanic quake was followed by a decrease in local tectonic quakes (Figure 4). Pattern showing an increase of deep volcanic quake can also be observed in Tambora eruption. Prior to the eruption of Tambora in August, deep volcanic quake frequency was increasing from 200 to 300. Local tectonic quakes were also increasing from 30 to 90.

Deep volcanic seismicity is occurred at depth of 10 to $60 \mathrm{~km}$ beneath volcanoes in a range of tectonic settings and this type of quakes has contributed to magma transport in the mid-to-lower crust and uppermost mantle (Chouet \& Matoza 2013, Matoza 2020). This seismicity extends down to mantle 
depths. Occurrence of deep volcanic seismicity has been reported having concurrence with the presence of volcanoes and their activities., Around 162 deep volcanic seismicity were detected between 1989 and 2002 beneath 11 volcanic centers in the Aleutian arc (Power et al. 2004). Between 1980 and 2009, more than 60 deep volcanic quakes were identified beneath 6 Cascades volcanic center and (Nichols et al. 2011, 11).

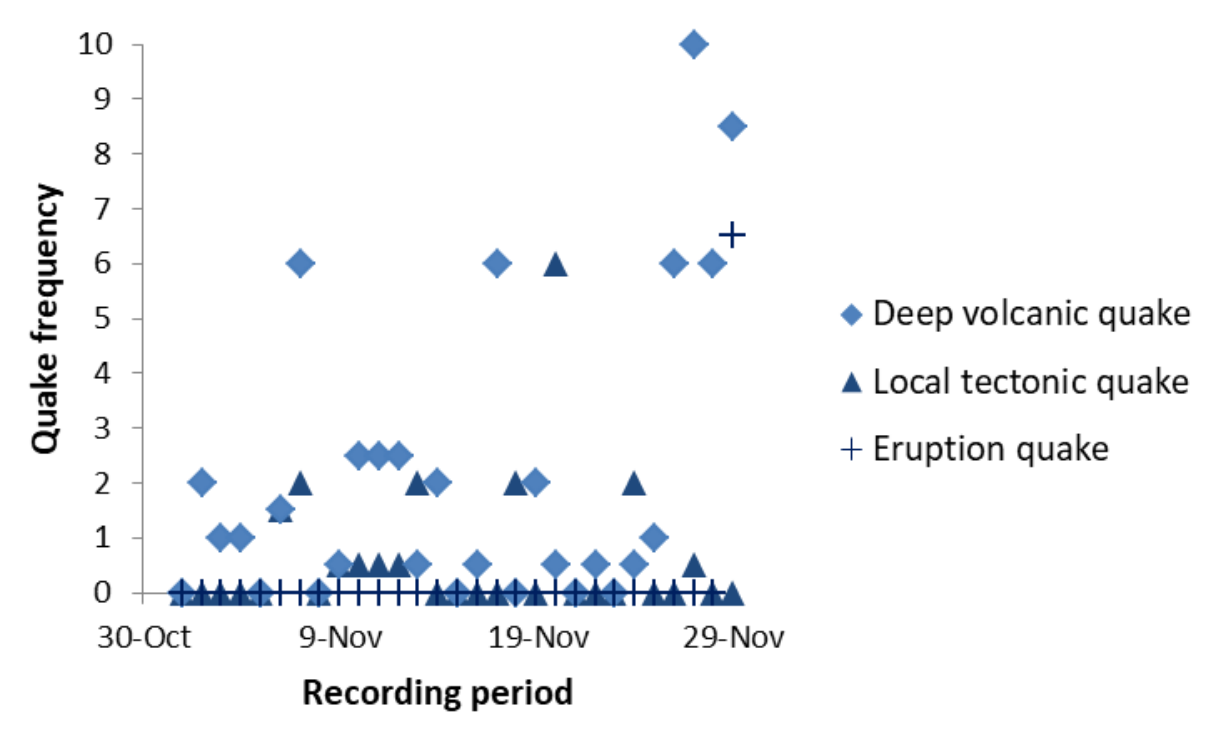

Figure 3. Frequency trends of deep volcanic, local tectonic and eruption quakes of mount Ile Lewotolok recorded within period of November 1-29, 2020

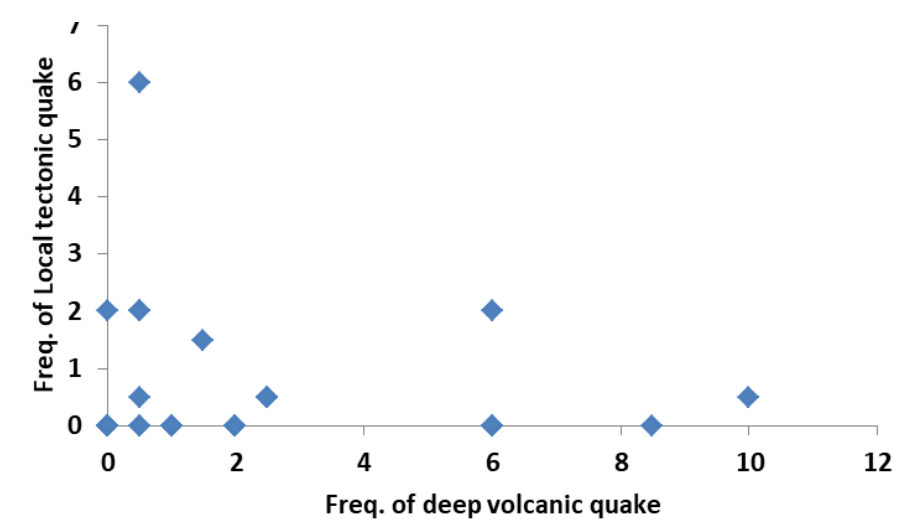

Figure 4. Correlations of deep volcanic with local tectonic quakes of mount lle Lewotolok recorded within period of November 1-29, 2020

In our study, it has observed an increase of deep volcano seismicity prior to the eruption. This situation indicates that deep volcano seismicity can be a precursor for the eruption. Mount Pinatubo eruption is in agreement with this finding. The Pinatubo eruption in 1991 has provided new evidence 
that deep volcano seismicity is potentially important eruption precursors since deep volcano seismicity has connected with deep magma transport in a subduction setting (White et al. 1996) and stress fields (Gudmundsson \& Philipp 2006, Manconi 2009, Roberto \& Silvia 2017). A stress field acting on active volcanoes can trigger volcanic seismicity and a volcano eruption. An additional stress imposed to a rock volume holding magma can cause a material failure if it is suddenly imposed. This material failure process can produce a characteristic strain release that can be detected by nearby monitoring stations as an accelerated seismic energy release (Cruz-Reyna 2010).

A similar increase in mid-to-lower crustal deep volcano seismicity was also observed about 10 months before the 1999 mount Shishaldin eruption in Alaska. In Shinmoe-dake and Kirishima volcanoes, presences of deep volcano seismicity at depths of 20-27 km have associated with the 2011 and 2018 eruptions. A large number of unique deep volcano seismicity occurred before the 2011 subplinian eruptions and it suggests that monitoring deep volcano seismicity may also be useful to predict eruptions in the future. Nishimura (2017) stated that large earthquakes with magnitude larger than 7.5 increase about $50 \%$ for eruptions at volcanoes within a distance of less than $200 \mathrm{~km}$.
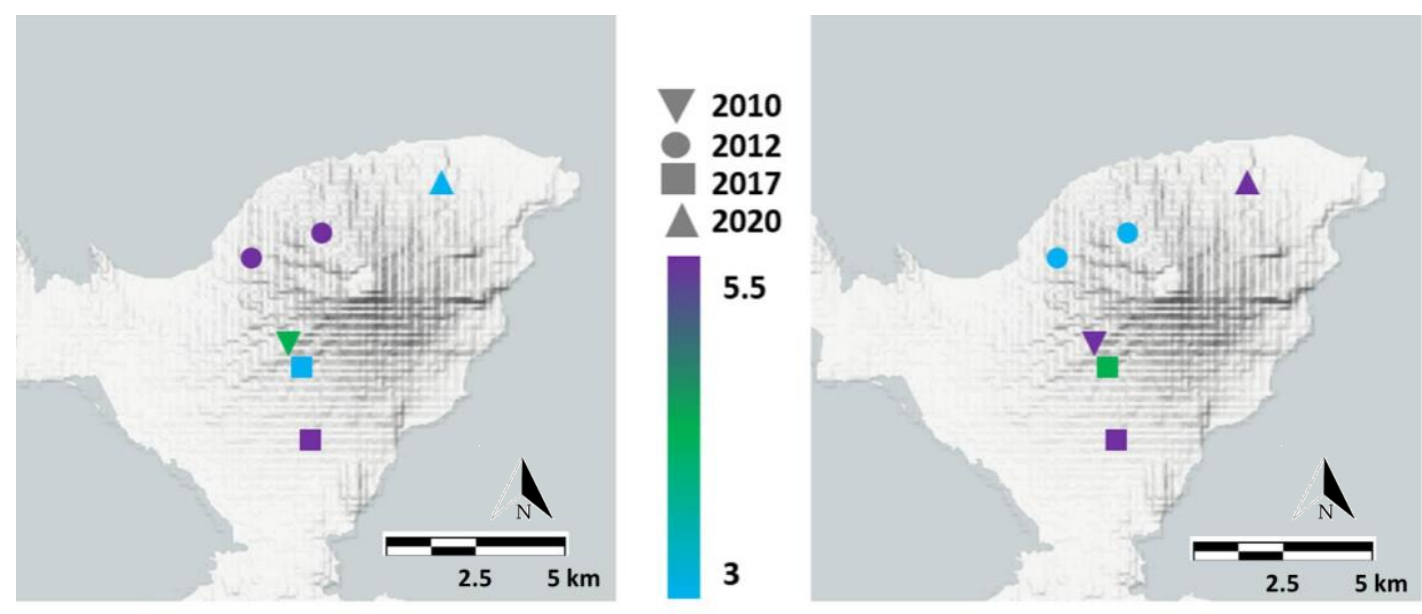

Figure 5. Distributions of tectonic quake magnitudes (left: $3-5.5)$ and depths (right: $10-20 \mathrm{~km}$ ) of Mt Ile Lewotolok recorded within period of 2010-2020

Figure 5 presents the historical records of tectonic seismic around Mt lle Lewotolok. Years 2012 and 2017 have recorded more tectonic activities. At this period, Mt lle Lewotolok has experienced several eruptions. In the year 2012, the eruption has happened in January 2012 while the quake was happened in October 2012. In 2017 and 2020, the quakes were recorded on October 10 (M 4.8) and 19 (M 3), 2017 and September 20, 2020. In 2017, the eruption was recorded on October 11, 2017, one day after the M 4.8 quakes. This historical seismicity records indicates the connection of tectonic that led to the several eruptions of Mt lle Lewotolok. The tectonic historical records demonstrated that the earthquakes were 
occurring almost exclusively in the same area within the distances of 3-4 km south west of the lle Lewotolok summit and at shallow depths of $10 \mathrm{~km}$ deep. In 2010, a M 4.5 was recorded at $10 \mathrm{~km}$ depth. In 2017, close to the quake record in 2010, two quake events have occurred at similar depth. The large first quake (M 4.8 at $10 \mathrm{~km}$ depth) happened on October 10, 2020 and it has been followed by the eruption on October 11, 2020 and followed by second quakes (M 3 at $11 \mathrm{~km}$ depth). The similar pattern was also observed in Mt Shishaldin. In this mountain, volcano began to erupt on April 19, 1999 after occurrence of a smaller swarm of quakes with magnitudes $M \leq 4.4$ on 13 April 1999.

According to historical records, the 2012 eruption of Mt lle Lewotolok might be related to the M 4.5 quake in 2010. The next eruption in 2017 was also related to the 2012 M 4.7-4.8 and 2017 M 4.8 quakes that occurred just within 1 day before the eruption. Examples of earthquakes prior volcanic activity can be found on local, regional and global scales. Eggert and Walter (2009) stated that the time between a tectonic earthquake and a volcanic eruption may vary from a few seconds to years with the distance between the events can reach up to thousands of kilometers, but is most evident in the near-field. In Mt Ile Lewotolok, the quakes were occurred within the distances of 3-4 km.

An assessment on historical quake records as determinant factors of eruption is still limited in Indonesia as a country that has numerous volcanoes. Whereas a recent study has assessed the determinant factors of Mount Sinabung eruption in 2010. In agreement to this study, the Mt Sinabung eruption was preceded by earthquakes. A large tectonic earthquake may amplify the probability of unrest at Sinabung and facilitate the intrusion of new magma (Kriswati et al. 2019).

\section{Conclusion}

Volcano eruption is not a stand alone geological process. Instead of depending on a single factor, an eruption is resulted from combined spatio-temporal geological process including tectonic and volcanic quakes. This study has provided empirical evidences of how series of spatially and temporally distributed quakes have affected the recent Mt lle Lewotolok eruption. The results confirm that the occurrence of repeated tectonic quakes at depth of $10 \mathrm{~km}$ may contribute to the past eruption in 2012 and 2017. In contrary to the effects of tectonic quakes, current eruption on November 2020 was affected by increasing frequencies of deep volcano seismicity prior to the eruption time.

Author correspondence: Andri Wibowo (paleobio2020@gmail.com)

\section{References}

Chouet BA, Matoza RS. 2013. A multi-decadal view of seismic methods for detecting precursors of magma movement and eruption. Journal of Volcanology and Geothermal Research, 
Cruz-Reyna S, Tárraga M, Ortiz R, Martínez-Bringas A. 2010. Tectonic earthquakes triggering volcanic seismicity and eruptions. Case studies at Tungurahua and Popocatépetl volcanoes. Journal of Volcanology and Geothermal Research. 193. 37-48.

Eggert S, Walter TR. 2009. Volcanic activity before and after large tectonic earthquakes: Observations and statistical significance. Tectonophysics 471: 14-26.

Gudmundsson A, Philipp SL. 2006. How local stress fields prevent volcanic eruptions. Journal of Volcanology and Geothermal Research. 158(3-4) : 257-268.

Hill DP, Pollitz F, Newhall C. 2002. Earthquake-volcano interactions. Physics Today. van Padang MN. 1951. Catalogue of the Active Volcanoes of Indonesia

Kriswati E, Meilano I, Iguchi M, Abidin HZ, Surono. 2019. An evaluation of the possibility of tectonic triggering of the Sinabung eruption. Journal of Volcanology and Geothermal Research. 382: 224-232.

Kurihara R, Obara K, Takeo A, Tanaka Y. 2019. Deep Low-Frequency Earthquakes Associated with the Eruptions of Shinmoe dake in Kirishima Volcanoes. Journal of Geophysical Research: Solid Earth.

Manconi A. 2009. Stress and Strain Field at Volcanoes Under Consideration of Material Heterogeneities.

Matoza RS. 2020. Seismicity from the deep magma system. Science 15: 708-709.

Nichols ML, Malone SD, Moran SC, Thelen WA. 2011. Deep long-period earthquakes beneath Washington and Oregon volcanoes. Journal of Volcanology and Geothermal Research. 200(3-4): 116128.

Nishimura T. 2017. Triggering of volcanic eruptions by large earthquakes. Geophys. Res. Lett. 44. 77507756

Pitt AM, Hill DP, Walter SW, Johnson MJS. 2002. Midcrustal, long-period earthquakes beneath northern California volcanic areas. Seismol. Res. Lett. 73(144).

Power JA, Stihler SD, White RA, Moran SC. 2004. Observations of deep long-period (DLP) seismic events beneath Aleutian arc volcanoes, 1989-2002. Journal of Volcanology and Geothermal Research. 138 (3-4): 243-266. Deep long-period earthquakes beneath Washington and Oregon volcanoes

Roberto S, Silvia M. 2017. Influence of Stress Field Changes on Eruption Initiation and Dynamics: A Review. Frontiers in Earth Science 5: 18.

White RA. 1996. in Fire and mud, eruptions and lahars of Mount Pinatubo, Philippines. C. G. Newhall, R. S. Punongbayan, Eds. (Univ. of Washington Press). 307-328.

White R, McCausland W. 2015. Volcano-Tectonic Earthquakes: a new tool for estimating intrusive volumes and forecasting eruptions. Journal of Volcanology and Geothermal Research. 309. 